\title{
Madras Lunatic Asylum: A Remarkable History in British India
}

\author{
Saumitra Basu* \\ (Received 01 December 2014; revised 13 October 2015)
}

\begin{abstract}
Concern for mental health has long been a part of Indian health cultures. Prior to colonial imperialism of India, the confinement of the mentally ill was not commonly practised in Indian society. In India the care of the mentally ill in asylums was a British innovation. The purpose of these asylums appeared to have been to alleviate society from those inflicted with mental disease. As a result the British established a number of lunatic asylums in different Presidencies of the then India. Madras lunatic asylum was one of them. Specifically this asylum was relatively free from maladies in comparison with the other asylums in colonial India. The aim of the present research is to assess the genesis of this asylum with emphasis to understand the major prerequisite for establishing Lunatic Asylums in Colonial India and specifically comprehend the perceptions about Lunacy by the colonial rulers. The present study explores the origin of the Madras lunatic asylum with its distinct non- controversial features, enactment of Indian Lunacy Acts, the role of Madras government and the new knowledge of asylum psychiatry under the colonial hegemony. The study reveals the function of the Madras lunatic asylum as an example of providing reception to both Europeans and Indians since its inception. Internal management, efficiency in curing the disease and low death rate which were evident in Madras lunatic asylum have been discussed in the present work. Control of corruptions within the asylum walls has also been observed. This in turn paved a new vista of psychiatry even in a colonial context.
\end{abstract}

Key words: Asylum psychiatry, Colonial discourse, Lunatic asylum, Madras, Mental health, Perception about lunacy,

\section{INTRODUCTION}

The history of asylums in India provides an opportunity to study the spread of ideas about mental illness, notions of care and responsibility for the mentally ill across cultures and time (Jain, 2003). Since time immemorial concern with mental health has been a part of Indian culture.

Like very few others, Indians have long been involved in constructing explanatory techniques for its alleviation. There are traditional physicians like the Vaids, the Hakims - many of whom also practice what we today call 'psychological medicine'. In addition there are palmists, a variety of shamans, whose therapeutic efforts combine elements from classical Indian astrology, medicine, alchemy and magic with beliefs and practices from folk and popular traditions.

(Mills, 2001).

The tradition of wandering including vagrancy was a recognized aspect of an ascetic lifestyle in India (Brumlik, 2014).

A very early reference to a wandering lunatic is to be found in the Buddhist Tamil epic, Manimegalai (Circa $2^{\text {nd }}$ century AD). The heroine Manimegalai encounters a severely disturbed individual. The song unfolds describing her encounter with a mad man on the way to the flower garden of Kaveripoompattinam, the famous east coast harbor of the early Cholas, which traded with Greece and Rome in the West, and the kingdoms of South East Asia including China.

(Somasundaram, 1987)

\footnotetext{
*Research Associate, Indian National Science Academy, AVISHIKTA - I, Flat 3B-302, 369/1 Purbachal Kalitala Road, Kolkata-700078, Email: bsoumitra2001@gmail.com
} 
Treatment of mentally ill was also a common practice in India throughout the ages.

Historical reference to the treatment of the mentally ill in the Chola period of Tamil history is to be found in the epigraph of King Veera Rajendra Deva (1063$69 \mathrm{AD})$ at the temple-hospital of Thirumukkudal near the sacred town of Kancheepuram in Tamil Nadu. (Somasundaram et.al.2014)

A brief historical overview on Indian Lunacy Act 1912 mentioned Mahmood Khilji (1436 1469) who established a mental hospital at Dhar near Mandu in Madhya Pradesh and Maulana Fazular Lah Hakim was appointed as the physician. (Somasundaram, 1987).

Traditional medical practitioners provided the necessary treatment as part of their practice long before the advent of modern medicine. Indian Philosophy attaches great importance to the concept of mental health. This is found in the Indian Philosophical text like Yogasūtra (Woods, 1914). For example, in our Hindu tradition, insanity was treated through Vedic prayer and Ayurvedic practices (Compson, Alexandra. Insanity, California College of Ayurveda,2004). In our ancient medical (Ayurveda) text, insanity has been mentioned in different Samhitas. For example in Caraka Samhita, Caraka makes this broad observation:

\begin{abstract}
When the mind is constantly afflicted by passion, hatred, anger, greed, excitement, fear, attachment, exertion, anxiety and grief and when he (the individual) is subjected to excessive physical assault; in these circumstances, the mind gets seriously affected and awareness is impaired. The dosas get vitiated and enter the hrdya (heart-region) and obstruct the channels of mind causing insanity. Insanity is to be known as the agitated or unsettled state of mind, awareness, perception, knowledge, memory, involvement, virtue, behaviour and conduct. (CS, $N \bar{\imath}, 7-4,5)$
\end{abstract}

Like Hindu tradition, Muslims also have a tradition of treating the mentally ill. Islamic medicine and psychiatric care were introduced to the Indian subcontinent in the $12^{\text {th }}$ and $13^{\text {th }}$ century, during the Muslim invasion of the region. Muslims in the Arabic world had established several hospitals for the mentally ill. The first such instance was al Qatai, Egypt, in 872 BC (approximately) (Prioreschi, 2001). In 1173 A D there was a large building at Baghdad called Almeraph Tan or House of Grace, to which the insane were brought from all parts of Persia where they received medical care until they recovered (Somasundaram, 1987). Sulemania asylum established in 1560 employed 150 persons to take care of not more than 20 patients who were treated very compassionately (Somasundaram, 1987).

From different ancient medical texts it is evident that treatment of mentally ill was not an uncommon phenomenon. But what was the specific perspective which instilled the colonial administrators to establish 'Lunatic asylums' to treat the insane in colonial India? Systematic study of the different scientific journals, medical records and public health reports of the $18^{\text {th }}$ and $19^{\text {th }}$ century India reveals that with the progression and reinvention of scientific discourse, late eighteenth and early nineteenth century witnessed billowy wave in the field of medicine and scientific discoveries. Many scientific observations and speculations were made over the causes of mental disorders particularly in the Western Medical Community. At that time, the major lacuna in the treatment of the mentally ill was a lack of training in diagnosis and treatment of mental diseases even in the West (Macpherson, 1856). Rather, confinement within the home and of shackling the inflicted was a common practice (Kolb, 1968). Lack of proper medical understanding was also revealed in the medical journals. Article written by Dr. T.A. Wise, published in the Monthly Journal of Medical Science, 1852, wrote,

moon and Indian climate causes seasons of insanity in India.

(Wise, 1852)

The rise of Lunatic asylum in colonial India started in 1740s when in Bombay a hospital was converted to a place for insanes at the cost of Rupees 125, Anna 0 and Paisa 45 (Maharashtra 
State Archives, Public Department Diary No. 19 of 1745-46, Consultation of $14^{\text {th }}$ March 1746, pp. $72-75)$. The first recorded evidence of such existence happened in 1787(Ernst, 1998). D.G.Crawford, in his medical treatise $A$ History of the Indian Medical Service: 1600 - 1913 (in Two volumes) wrote about coming up of Lunatic Asylums in the capital of British India, Calcutta (Crawford, 1914). Possibly the first establishment for treating the mentally ill was the one, established by Surgeon George M. Kenderline in Calcutta in 1787. But it could not be granted 'official recognition' because the surgeon had been previously dismissed from service for negligence of duty

(Army surgeon's manual for the use of Medical
officers, cadets, chaplains, and hospital stewards,
containing the Regulations op the medical
department, all general orders from the war
department, and circulars from the Surgeon-
general's office. From January 1st, 1861, to July
1 st, 1864, by William Grace, of Washington,
DC).

In the year 1788 , a private asylum was established by William Dick in Calcutta for insane officers and men, and civilians of various stations (Love, H.D. Vestiges of old Madras 1640 - 1800, London, 1913). In 1795, James Smith, the Commander in Chief of the Bengal Army wrote a letter to the Governor General Warren Hastings for establishing Lunatic asylum.

In 1795, the Commander in Chief of the Bengal Army wrote to the Governor General proposing to establish a house at Monghyr in modern day Bihar in which mad sepoys could be incarcerated. At the time there were three such soldiers locked up in the guard room at the invalid depot in that garrison, a state of affairs that the Commander considered highly unsuitable. The Governor General's response was very positive as he agreed that this was a good idea and as such he sanctioned a facility to be designed for the reception of about twenty patients, which could be expanded further should there be the demand.

(Letters received from Bengal, 14 May 1795,para 27, National Archives of India, Government of Bengal, Military Proceedings).
Thus the development of lunatic asylums was apparent in the early colonial period from 1745 to 1857 till the first movement for Indian Independence was started. After the 1857 rebellion, the British Crown succeeded the East India Company as rulers of India. In 1858 the Lunacy Act was enacted, detailing the procedures for the establishment of the mental hospitals and for admitting patients. This act was modified in greater details in 1888 (Somasundaram,1987) . After 1858, an expansion of colonization in India took place. The mid-colonial period from 1858-1918 witnessed a steady growth in the development of mental asylums. This period was significant for the enactment of the first Lunacy Act in the year 1858. New asylums were also built at Patna, Dacca(1872), Calcutta, Berhampur, Waltair(1871), Trichinapally (1871), Colaba, Poona, Dharwar, Ahmedabad, Ratnagiri, Hyderabad (Sind), Jabalpur(1866), Banaras(1854), Agra(1858), Bareilly(1862), Tezpur (1876) and Lahore (Ernst,2001). Under the Indian Lunacy Act 1912, a European Lunatic Asylum was established in Bhowanipore (Calcutta) for European patients, which later closed down after the establishment of the European Hospital at Ranchi in 1918. Mental Asylum at Ranchi first opened in 1918 as a hospital for European patients (Nizamie et.al. 2008). The origin of psychiatric rehabilitation in India can be traced to innovative service programs which were initiated at the Central Institute of Psychiatry (CIP) in 1922 when Occupational Therapy Unit started at this place (Nizamie et.al, 2008). Girindra Shekhar Bose founded the Indian Psychoanalytical Association in 1922 (Ramana,1964) in Calcutta and Berkeley-Hill started the Indian Association for Mental Hygiene at Ranchi (Berkeley Hill,1924). The first psychiatric outpatient service, precursor to the present-day general hospital psychiatric units (GHPU), was set up at the R.G. Kar Medical College, Calcutta in 1933 by Girindra Shekhar Bose. This was followed by a surge of such units with Masani opening at JJ Hospital, Bombay in 
1938 (Wig and Awasthi,2003) and Dhunjibhoy opened one day weekly clinic at Prince of Wales Medical College (now Patna Medical College) in 1939 (Wig and Awasthi, 2003).

In 1946, a Health Survey and Development Committee, popularly known as the "Bhore Committee," surveyed mental hospitals. The Health Survey and Development Committee report submitted by Col. Moore Taylor in 1946 reported numerical and professional inadequacy and suggested a focus on training of personnel and students in psychiatry, promotion of occupational and diversionary therapies. The committee suggested improvisation and modernization of most hospitals, attachment to medical colleges, and establishment of proper mental health. The World War II saw a separation of military psychiatry from psychiatry in general. It is at this juncture of time the history of modern psychiatry in India seemed to have returned to its origin.

The above in brief is the illustrious journey of Lunatic Asylums in different parts of colonial India. But the present research specifically picks up Madras Lunatic Asylum for three reasons. These are (i) since its inception from 1794, provision for the reception of both Europeans and Indians prevailed, though there were separate wards for different races, (ii) even in the early nineteenth century, this asylum was not only built by a medical practitioner but it was owned by medics, (iii) internal management, cure efficiency and low death rate. These were the three most favourable features of Madras Lunatic Asylum. Besides, growth of Madras Lunatic Asylum was free from all kinds of financial malpractices in comparison with other Asylums even in the early nineteenth century (India Office Record, Medical Bulletin to Government, 17-3-1852, Md, Mill, Proceedings, 6-4-1852,62). Now it is imperative to understand the major prerequisite criteria which helped in establishing the Lunatic Asylums in Colonial India and specifically the perceptions of the colonial rulers regarding lunacy.

\section{Asylum Provision and the Colonial Perception about Lunacy}

Waltraud Ernst in Mad Tales from the Raj:

\begin{abstract}
The European Insane in British India, 1800-1858 demonstrates that in late eighteenth-century India, British colonial psychiatry was preoccupied with Europeans' psychological capacity to live "under Oriental light, (Ernst,1991)
\end{abstract}

The advancement of imperial power in colonial India motivated the development of psychiatric infrastructure in India. In the early nineteenth century, asylums had begun as private business which was gradually taken over by the British administration. Asylums thus existed with the East India Company's approval in the major presidencies of Madras, Bombay, and Calcutta almost since the arrival of significant numbers of soldiers and civilian colonialists. Around 1850s, all these small private madhouses became large public institutions. From the very beginning, like other private endeavours, mental health care investors had no medical training. They built houses of confinement for business, ensuring profitability by tapping a concern for public order within the European community. Psychiatry in India also mirrored practices in England, where the government's use of privately operated madhouses to preserve public order was common place until Parliament mandated the establishment of public lunatic asylums in 1845.

However, psychiatric care in India was marked by some important features. Large asylums located in the Calcutta, Bombay, and Madras served mostly European patients. A number of smaller asylums confined the Indian insanes. Medical history of British India illustrated the peculiarities (India Office Medical Records of British India, 1852) of confinement for European soldiers and civilians from the late eighteenth century to the Sepoy Mutiny. British institutions in India reflected European humanitarian concerns for disciplining madness. Maintaining superior conditions than those in jails and workhouses 
were essential because "madness unlike destitution crossed barriers of social class." This advancement in understanding the discipline was not only reflected in the therapy of asylums in India but it left its mark in the arena of administration and even in architecture (Hill, 1924).

In spite of such development, racial difference was evident with respect to the confinement and treatment. European doctors monopolized the medical profession, and compelled Indians to occupy the most tedious positions in asylums. European and Indian patients were confined in separate institutions. There were few instances where Europeans and Indians were interned together but Europeans enjoyed better living conditions.

For example in Bombay's asylum at mid-eighteenth century, doctors offered half the institution's space to twenty-one Europeans, while seventy-two Indians were packed into the remaining half.

(Keller, 2001).

In spite of constant official complaints regarding the horrible conditions that resulted from the compulsive segregation of patients based on racial discrimination, authorities never considered altering such practices. Therapeutic tendencies manifested racism in more alarming ways. Psychiatrists in Britain advocated work as a means of "moral management" of mental illness, on the other hand British psychiatrists in India designated hard labour "impracticable, to Europeans" because of the harsh climate. This kind of view demarcated the social class in a very crude way. Physicians prescribed that soldiers and working-class Europeans should not work in asylums, while in the same institutions Indian patients were forced into exhaustive labour as part of their therapy. Thus psychiatrists in Britain and India differed on the issue of controlling violent patients. British psychiatrist viewed handcuffs and leg irons as barbaric symbols of the asylum's dubious past, but they differed in their views regarding Indian patients. Indian orderlies and nurses were largely responsible for controlling disobedient "native" patients. Before the development of psychoactive drugs for calming patients, mechanical controls were the only means for avoiding Europeans' ultimate humiliation - physical domination by native orderlies (Ernst, 1997). As a consequence of this concern, various measures were implemented to preserve the prestige of the ruling class. Thus it can be said that asylum provision in colonial India were made mainly for temporary custody of European insanes (European insanes awaiting embarkation to Britain). In Mad Tales from the Raj, Waltrud Ernst effectively portrayed this colonial hegemony, conditions of confinement and therapy for studying the intersection of race and psychiatric practices in India. Besides, the intersection of class and race in the Raj and the manner in which psychiatrists and administrators employed social discrimination to maintain white supremacy in India also deepens our understanding about the asylum provision in colonial India in a more systematic manner.

The asylums therefore functioned as key symbols of the civilizing mission. As markers of European medical superiority, institutions propagated the myth of medicine as an important means of colonization despite their limitations in actually confining and treating patients. Though the number of patients confined and treated was tiny, it "contributed to the maintenance of the selfimage of the British as a superior people whose charitable humanitarianism and rational, scientific achievements made colonial rule appear morally beneficial and legitimate".

(Ernst, 1997).

Next to asylum provision, it is crucial to understand the perception of lunacy by the colonial rulers. How did they identify a person as lunatic / insane or what are the causes of insanity? In keeping with Western medical tradition, the British chose to pass laws in order to define who was a lunatic and how they should be treated? Due to cultural and religious differences, very little similarities thus existed between Britain and India regarding the concept of lunacy. The term lunacy 
comes from the French word for moon, lune and is taken from the old belief that the moon was responsible for all disorders of the mind. British definition of a lunatic can be seen in the $18^{\text {th }}$ century treatise, Commentaries on the Laws of England. Blackstone in his Commentaries on the Laws of England (Cooley,1871), (Book 1, Chapter 8, "Of the Rights of Persons"), comprehensively covered the topic as follows, and the law was in the mid-1800s: "A lunatic, or non compos mentis, is one who has had understanding, but by disease, grief, or other accident has lost the use of his reason. A lunatic is indeed properly one that has lucid intervals; sometimes enjoying his senses, and sometimes not, and that frequently depending upon the change of the moon". The terminology for lunacy was phrased loosely enough to cover a wide range of issues and socially troublesome behaviours.

Science historian Howard Markel discusses the origins of the word moon and some of the lore surrounding it, including a book by the English Bishop Francis Godwin entitled The Man in the Moone, which recounts a science fiction-style voyage to the moon. The Latin word for moon, of course, is Luna. Luna was the Roman incarnation of Selene, the Greek goddess personifying the moon. (The word Selene likely comes from a Greek root selas, for brightness). The adjective lunar is still used today when referring to the activities and features of the moon. But in Antiquity, lunar was also often employed in reference to both a woman's menstrual cycle and to insanity, (i.e., lunacy, lunatic) (Raison et.al., 1999).

Another source mentioned that the term lunatic originally referred mainly to epilepsy and "madness" as diseases caused by the Moon. By the $4^{\text {th }}$ and $5^{\text {th }}$ centuries astrologers began to commonly use the term to refer to neurological and psychiatric diseases. Philosophers such as Aristotle and Pliny the elders argued that the full Moon induced insane individuals with bipolar disorder by providing light during nights which would otherwise have been dark, and affecting susceptible individuals through the well-known route of sleep deprivation(Harrison,2000). It was also a common belief that the Moon influenced fevers, rheumatism, episodes of epilepsy and other diseases.

Next to terminology, the most important thing was who were the inmates of these asylums?

18th Century Indian Medical Records reported that irrespective of social class and category of people like soldiers, students, servants, labourers, beggars, coolies, cultivators, housewives, prostitutes, shopkeepers, fisherman, goldsmith, merchants, singers, tailors, writers and many others generally came to these asylums. However, sufficient statistics is not available.

(Annual Report on Lunatic Asylums of Bengal for the year 1886, West Bengal State Archives, Municipal Department, Medical Branch, Appendix, July 1887).

During the colonial Empire, the occurrence of mental illness had been reported in the statistical tables extensively. This attempt to identify and categorise mental illness. The reports clearly reveal that how insanity had been transformed into a condition which could be authoritatively diagnosed, certified and dealt with by a group of legally recognised experts (Scull,1980). Emphasis was given more on physical causes such as small-pox, venereal disease and typhoid up to the early 1900s than mental. For example, the 1882- 83 report on Madras, made a split between alleged physical and moral causes of insanity. Thus physical causes included epilepsy, fever, sunstroke, over-study and moral causes, such as grief, fear, confinement in jail and infidelity. Masturbation and witchcraft were also commonly documented as physical causes of insanity. Their inclusion may have provided the rationale that the deviant, dangerous indigenous population required 'civilising' by western methods ( Annual Report of the Lunatic Asylums in the Madras Presidency during the year 1882-83, pp.5). 
The differences in opinion among colonial staff about the moral causes of insanity are seen in 1881:

\begin{abstract}
When we come into the domain of "moral causes" we are at once involved in much uncertainty. I have often expressed my doubts of natives going mad from grief, anger and fear. However, as these causes were attributed by the Medical and District officers I have included them in this Statement.
\end{abstract}

An 1871 report shows some alleged reasons for insanity as being bitten by a jackal, a peculiar view on religion and 'got sick with fever and suddenly turned out as mad.' Successive changes in medical definitions thus observed in 1946 when mental illnesses were listed as manic depressive psychosis, schizophrenia, mania, paranoia, mental deficiency. Furthermore, examining causes and types of insanity in these reports reveal not only changing socio-cultural perceptions of the colonial rulers but also their colonial subjects and madness itself. Thus it cannot be an overstatement that the British classification of 'lunatic' in India was an ambiguous term that covered a wide range of illnesses and social improprieties. Different medical records revealed that very little had been reported about the actual mental disorders of the patients (Millard, 2012).

\section{Madras Lunatic Asylum}

In the year 1793, Assistant Surgeon Valentine Connolly, Secretary to the Medical Board proposed to the government a plan to set up a Lunatic Asylum in Madras. Assistant Surgeon Valentine Connolly, wrote to the medical board saying that -

Want of an asylum on the coast has been long a matter of regret, and in some instances it has been attended with dreadful consequences

(Madras Military Letter,18-2-1794,88, Madras Military Despatch,6-5-1795,72, Madras Military Letter,16-10-1794,3).

Suggestions for the asylum included detailed plans for buildings and staff, with a payment from the company for each patient admitted to the asylum. The asylum at Madras was

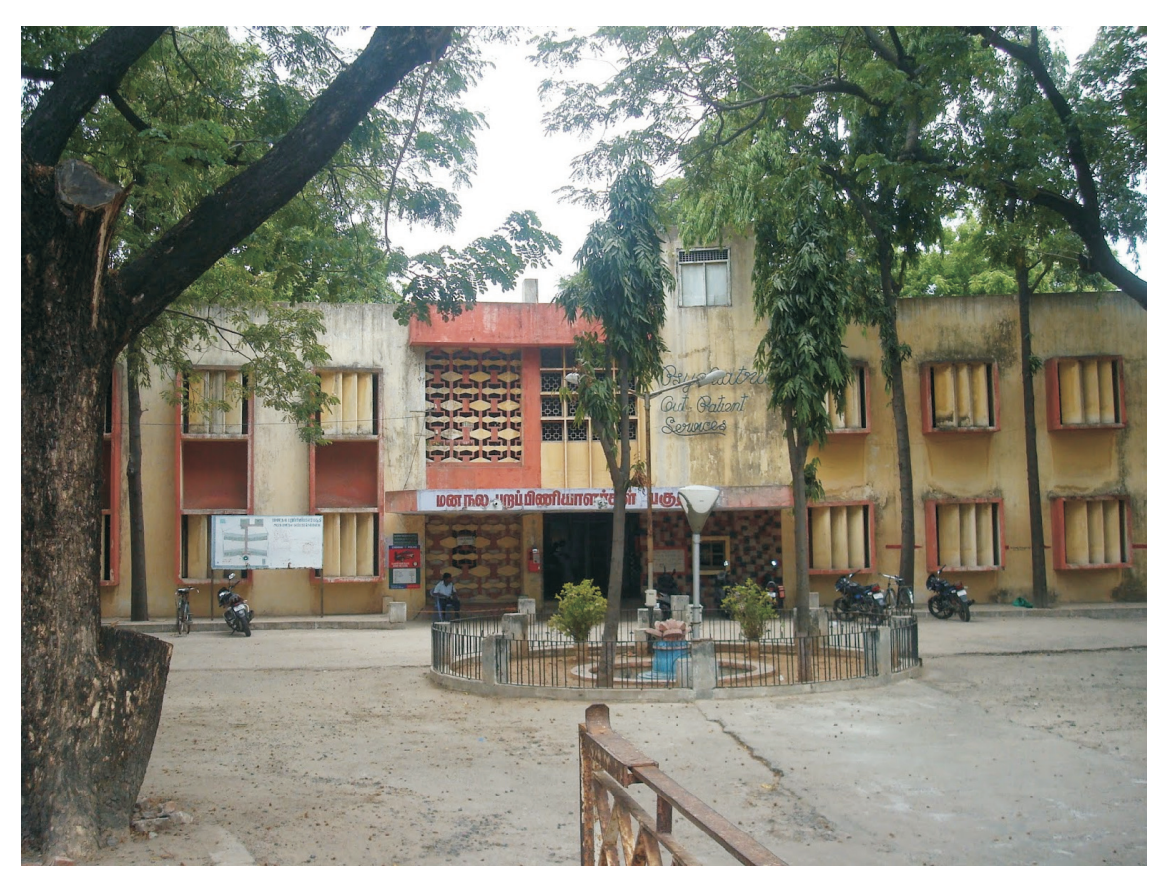

Pic: Madras Lunatic Asylum

Source: http://chennaimadras.blogspot.in/2014/05/not-all-there.html 
ordered to be built in 1793, for sixteen patients, and given a generous endowment and land, on the provision that no rent was to be paid as long as the building was devoted to public purposes (Subba Reddy, 1947).

The East India Company, the then administrative authority, for Fort St. George and its surrounding areas, appointed Surgeon Valentine Connolly as in charge of the Asylum. Connolly lends his house to accommodate persons of unsound mind. The premises, taken on lease for Rs. 825 per month, and comprised 45 acres of land at a nominal quit rent of 51 pagodas per annum. The Asylum opened there on 1st October 1794 and was meant for mentally ill Europeans and 'Eurasians'. Subsequently, Surgeon Maurice Fitzgerald held charge till 1803 and was followed by John Goulde. At that time, the institution could accommodate only twenty persons. It appears to have remained Connolly's property till he sold it to Dr. Dalton, with the Government paying Rs. 828/- per month for its use. Dalton rebuilt the whole facility, enlarging the accommodation, and it was called 'Dalton's Mad House'. This is now part of the medical college (Somasundaram, 2008). However, the description of the Madras Lunatic Asylum was published in the Report on the Medical Topography and Statistics of the Presidency Division of the Madras Army, Compiled from the Records of the Medical Board Office, published by order of Government Madras, 1842 is as follows -

The lunatic asylum is situated at Kilpauk, a retired part of the environs of Madras, about two miles and a half west from Fort St. George, placed in the middle of an enclosed square piece of ground about thirteen English acres in extent. The ground presents a level surface of turf, with but little vegetation, beyond a few coconut trees, at its eastern angles, the situation is rather low and the soil deep, and clayey.

The building which is constructed of brick and terraced consists of three quadrangles of one story, on the inner side of which are arranged the apartments or cells for the patients, each having its door opening into the square and opposite to it a barred window facing outwards. The whole building is surrounded generally at a distance of about fifty feet, by a curtain wall, nearly six feet high. The entrance to the great square is on the Eastern face on one of which the Dispensary offices and Commissariate Hospital stores, are placed and on the other are apartments for the resident Subordinate Medical Attendants, and cook rooms none of which open into the Square. There are twenty four cells in the large quadrangle, and in the centre of the area, which is about 140 feet square, is a large bath room, amply supplied with water. In each of the two smaller quadrangles are six single Cells and four double ones and though somewhat smaller than the European cells, they are equally well ventilated. The cells and verandahs of the whole building are floored with square bricks, and to admit of the more ready purification of the apartments of such patients as are unattentive to cleanliness, the floor of each cells has a slight inclination to one of the angles, on the outward face, where a small circular opening through the wall gives ready exit to the water used in washing the floor and is carried off by drains round the building keeping the whole perfectly dry.

Extent of accommodation- The asylum contains fifty six separate apartments for patients; and this accommodation has been found sufficiently extensive although a separate cell is invariably allotted to each individual, the number of patients in the asylum for many years past but rarely amounted to fifty at any one time. Long verandahs and shaded walks in the Square afford convenient space for moderate exercises but all patients whose cases admit of it are induced in favourable weather, to take exercise in the outer enclosure every morning and evening, on a circular walk on front of the Asylum. Observations on the Sick treated, The site of the institution is apparently healthy, for during the last fifteen years no disease has prevailed amongst its inmates, which could be fairly attributed to its locality.

(Report on the Medical Topography and statistics of the Presidency Division of the Madras Army, Government of Madras, 1842).

Although the detailed report of the asylum reveals that the space for accommodation, overall 
environment and cleanliness was adequate for the asylum inmates, the building structure of the asylum possessed some typical structural features of Indian military barrack where air circulation indicates structural defectiveness. But in spite of some structural defectiveness, inappropriate allotment of space and other unwanted sufferings, inmates did not suffer a lot from health hazards. This was obviously a surprising feature of this asylum in comparison with other asylum inmates in the early $19^{\text {th }}$ century colonial India (Annual Medical Report of the Lunatic Asylum Madras for the year 1878-79).

From different Medical Reports of British India, it is clearly revealed that from the end of the $18^{\text {th }}$ century, Lunatic asylums in British India (whether for Europeans or for Indians) was supervised by European Surgeons. But they did not spend much of their working time in the respective asylum rather they spent more time on private practice. Thus the management of the asylum and execution of the (Annual Report of the Insane Asylums in Bengal, 1869) Superintendents' guidelines were almost shouldered by the Indian sub assistants. However, the important factors which used to be taken into account while treating the insanes were race as evident in the colour of skin, social class and gender. The Government's rate and care pattern was clearly defined for the betterment of the military insanes according to their previous affiliation with the company's service. But the task was crucial for other general persons. Several disputes thus arose in evaluating an insane's class position (Madras Military Despatch, 20-8-1823, 40f, Report of Medical Board,14-3-1808, Minute of Second Member of Medical Board,14-3-1808, Madras Military Proceedings, 26-4-1808,2401,).

Within the three main asylums of British India, except some intra institutional variation, the major determinants of room allocation were racial background, social class and gender. Similarly, the dietary arrangements, provision of general services, cure and mortality rate also depended on the patients' class and race. No effective recommendations were thus made by the Presidency Medical Boards to ensure a full direct regime for lower class inmates. Patients' involvement in work and recreational activities, which were the main constituent of the contemporary system of 'moral treatment' again depended on patients' social class and race. In terms of daily routine of the inmates, European Lunatic asylums were not at all free from controversy. European inmates enjoyed some freedom to move about their wards, to find amusement in reading books, newspaper, playing cards etc. and Madras asylum was no exception to this phenomenon. Up to 1840 s, European insanes who were admitted to the Madras lunatic asylum could enjoy considerable entertainment. The spatial constraints made possible greater freedom of contact between inmates of different cultural background. In the Madras Lunatic asylum class specific confinement among Europeans was also enforced during earlier decades of the 19th century. By the mid $19^{\text {th }}$ century, the condition of the asylum deteriorated (Ernst, 1998).

\footnotetext{
Madras Medical Board Military Proceedings 1846, reported that the Superintending Surgeon of the Presidency's Hospitals, had on a routine inspection observed that the precarious condition of the asylum building. But when the Medical Board authority got the letter of the Superintending Surgeon, they rejected that letter. Rather the asylum medical authority claimed it most convenient and safe for the inmates.
}

However, since 1799 to 1850 , steady increase was thus observed in the asylum population. In comparison with the European insanes, the number of Eurasian and Indian patients increased drastically. In case of upper class Europeans social distance between the races were maintained. Even the mad members of the Europeans used to keep a distance from Indians and lower class Europeans. But the maintenance was inferior among the Eurasians or Indians (India Office Record, Report of the Medical Bulletin,152-1808; Military Medical Proceedings,4-3- 
$1808,153 \mathrm{ff}, 2400 \mathrm{ff}$, Medical Bulletin to G-iC,9-2-1821; Military Medical Proceedings, 9-2-1821,12, Military Board to G-i-C,28-8-1846; Military Medical Proceedings,29-9-1846,441; Medical Board to Government,10-1-1852; Military Medical Proceedings,23-1-1852,10).

In 1851, for example, a Captain J Campbell who had been certified as a 'criminal lunatic' was not admitted to the asylum because it was regarded as 'unsuited for persons of his class'. Instead he was confined in the local prison, where he occupied a large part of the premises (Experts and Criminal Lunatics". British Medical Journal, February 20, 1864, pp.208).

However, 1821 onwards, due to overcrowding of insanes, extensive repair, structural improvement and rearrangement of the asylum, European insanes were sent to their homeland.

As revealed from Madras Military Proceedings 1820, in May 1820 the Court of Directors of the East India Company informed the administrative authorities in Madras in respect to European insanes. The Court had approved the Bengal Government's policy of sending European insanes to England and declared the same provision should be made for the Madras Lunatic asylum also.

But the situation became reverse for Indian insanes. In case of weak Indian insanes (sometime designated as 'harmless idiots'), they were transferred to Mongear Choultry or at jail in the Black town. This was a routine practice from 1837 to 1844 . For this kind of practice, overcrowding became a common phenomenon to the institution to a great extent (India Office Record, Medical Publications, 26-5-1824,46). By 1846, the Military Board strongly recommended new construction of asylum due to unsafe condition of the asylum (India Office Record, Military Bulletin to G-iC,28-8-1846; Military Medical Proceedings, 299-1846, 441). In spite of this recommendation, several intervening social factors created severe constraints. But the alarming reports of the Madras Military Medical Board 1849 - 1850, instilled the Madras Government to think over the issue again (India Office Record, Medical Military Department, 11-9-1850,55,Md,Mil,D., 20-8-1851,46).

Finally in 1851, this recommendation was approved to construct a new building (India Office Record, Md, Mil,L., 31-3-1852-53). After the approval, the availability of open and spacious location for the construction of new lunatic asylum became a serious concern. Advertisement was published in the Official Gazette and ultimately land was purchased at Locock Garden (India Office Record, Md, Mil,L., 24-4-1852,10.). The Madras Lunatic Asylum was sanctioned by the then government at the erstwhile Madras Presidency in G.O. No. 26 Judicial, dated 7th January 1867(India Office Record; Cranford, 1914.). The asylum was constructed on a $661 / 2$-acre site in Locock's Garden outside the Municipal limits. It started functioning on 15th May 1871 with 145 patients and Surgeon John Murray MD as Superintendent with residential quarters inside the premises. Finally in 1871 the new construction of the asylum was completed and the insane inmates were transferred to the new premises (Subramanian, 2004).

\section{Indian Lunacy Acts and the Madras GovernMENT}

In India, as in other parts of the world, the traditional approach to the care of the mentally ill, during the last two hundred years, was custodial rather than therapeutic (Banerjee, 2001). In India, Western healing practices for the mentally ill was introduced by the East India Company (Sharma,1990). During colonial era, to create public awareness about mental patients several laws were enacted to regulate asylums, prisons and other associated matters as a whole. These were English Act of 1774 which were replaced 
by Country Asylum Act of 1808 . This was again replaced by Lunatic Act, Lunatic Asylum and Pauper Lunatics Act of 1845(Sharma, Ibid). However, at the beginning of the late $18^{\text {th }}$ century, it was believed by the British medical experts and administrators that tropical climate was one of the major causes of mental disorders. The most important thing was that all these initiatives were exclusively for the European soldiers. Even after their admission in a mental hospital, if they did not improve they were sent to England for further treatment and the costs were borne by the East India Company. But with the passage of time, this financial burden was called into question. In order to regulate this matter, in the year 1851 'Lunatics Removal Act' was passed. In the following years three subsequent Amendments were enacted. These were Lunacy Regulation Act of 1853, Lunatic Care Treatment Act 1853 and Lunatic Asylums Act 1853 (Weiss, 1983).

In the year 1858 when IndianAdministration took over by the British Empire, further laws were enacted to control, care and treat the mentally ill patients. These were The Lunacy Act of 1858, the Indian Lunatic Asylums Act 1858 etc. All these Lunatic Acts not only provided suitable guidelines for establishing lunatic asylums but also gave an idea about the admission of the mental patients. After enactment of these laws a number of lunatic asylums were established in different Presidencies of colonial India where insanes were admitted for mental treatment (Selections from the records of the Government of Bengal No. XXXVIII, Calcutta, 1858). Thus the existing British scenario existing in the colonial India and the prevailing socio-political scenario prevailing in the mid nineteenth century India served as the background of the lunacy legislation in that period. As a consequence, the various Acts of 1858 naturally reflected the legalistic frame for the management of the mentally ill. In course of time, this Act was modified by a committee appointed in Bengal in 1888. After modification, elaborate instructions and guidelines for the admission and treatment of criminal lunatics were given. But it is worth mentioning that by the end of the nineteenth century, overcrowding of the insanes made an adverse impact on the overall living condition of the insanes (Trivedi, 2002).

In such a colonial set up, during the beginning of the twentieth century when Swadeshi fragrance was blooming in the air, the distressed condition of these asylums drew attention of the Indian intelligentsia. They made severe protest against this malady through press which in turn reflected even in the British Parliament. However, this scenario ended in the Vice regal Lodge of Simla on Monday the $18^{\text {th }}$ September 1911 with Baron Hardinge of Penshurst presiding over the Council of the Governor General of India. The Hon'ble Mr. Jenkins introduced a Bill to consolidate and amend the law relating to lunacy. The intention was to consolidate the various lunacy laws in India and to introduce certain amendments and especially to bring the law in certain important particulars in line with the modern English law i.e. the Lunacy Act 1891(Governor General of India, Proceedings of the Government of India Legislative Council, Volume-I, Superintendent, Government Printing, India, Calcutta).

After a careful consideration by the Council, with Hon'ble Sir Guy Fleertwood Wilson as President, the Bill was passed as the Indian Lunacy Act 1912. This Act enumerated the procedures in Sections 5 to 11 and 18 to 20, replacing Section 7 of the Lunatic Asylum Act 1858. But the same fear of false detention of insane people was reflected in the passage. Here the role of the then Madras Government was really praiseworthy. The Governor of Madras, Sir Thomas David Gibson Carmichael in his letter to the Governor General on this subject made a paradigm shift.

In the opinion of this Government, the necessity for a reception order issued by a Magistrate has not been established in Madras. Regarded as an 
additional protection from the risk of improper confinement, the new procedure has no clear advantages over that embodied in the existing law, for the Magistrate is very unlikely to refuse to act upon the two medical certificates and from the point of view of the lunatics' relatives there is the objection that the provision of the Bill will unnecessarily complicate procedure and even though the enquiries are held in camera, will increase very largely the probability of publicity.

(Governor of Madras, Letter to the Government of India, Legislative Department, No. II, Public, 29-1-12).

In response to this letter, the Governor suggested to disqualify the Superintendent or any Medical Officer attached to an asylum from issuing a certificate for admission. However, this suggestion was not incorporated in the Act. Undoubtedly, it was the credit of the Madras Government, who raised the issue that an additional category of patients' voluntary boarders should be included in the Act. Finally the provision of the Scottish Law Section 15 of 29 and 30 Vict. Chapter 51 , which allows admission of uncertified cases as voluntary boarders in asylums (Somasundaram, 1987).

The enactment of Indian Lunacy Act 1912 can be symbolized as historical trajectory which in turn drastically altered the whole system of Mental Health Services and administration even in British India. With the 1858 Lunacy Acts, native lunatic asylums occupied an uneven position between medical and judicial dichotomy of this colonial government. After the Indian Lunacy Act 1912, mental health supervision was released from the grip of the Inspector General of Police and Psychiatrists were appointed as full time officers in mental hospitals. Therefore, it is pertinent to mention that by the enactment of the 1912 Act, these asylums transformed into exemplary colonial institutions, guided by psychiatric doctrine and were filled with Western-trained Indian doctors who never allowed any other alternative belief systems in this colonial space. Provision of this Act paid more attention to increase the legal safeguard against wrongful imprisonment and proposed rigorous criteria for certification of the mentally ill. We pay our homage to the then Madras Government whose careful and deep insight made possible to include 'voluntary admission in the Indian Lunacy Act' (Somasundaram, 1987).

\section{Asylum Psychiatry and Colonial Discourse in the Nineteenth Century INDIA}

Colonial discourses on asylums for lunatics in British India as a part of the new discipline of mental science took prominence in mid nineteenth century (Basu, 2004). Medical journals, Proceedings, Official records revealed that during this period, the discourse of asylum psychiatry were mainly concerned with enactment of new laws, acts, treatment and management of insanes. The confinement of the insane in purpose-built institutions spanned the modern western world. Between 1800 and 1914, no western country was spared the rapid construction of asylums and an apparently insatiable demand for institutional accommodation (Wright, 1997). The asylums and psychiatric practices not only emerged in the West but also spread across other parts of the world. Colonial India was also not an exception. The new establishment of psychiatry engulfed the wisdom of the native (Hochmuth, 2006). In this context, in the article on Emergence of a Marginal Science in a Colonial City: Reading Psychiatry in Bengali Periodicals, the observation of Amit Ranjan Basu (Basu,2004) is worth mentioning -

Basu observed that the history of colonial psychiatry in India is a scholarly concern exploring both the context of domination and racially informed medical practices. From various perspectives, these writings showed the powerful attempts of colonial psychiatry to homogenize a plural culture of healing. Through colonial records and numerous Bengali texts, he attempted to reconstruct a process that produced psychiatry. 
He also discussed the emergence of asylum psychiatry in the nineteenth century and the milieu of scientific writings in colonial Bengal. He argued that asylum practice informed with a new knowledge was a disjuncture from the prevailing indigenous practices. Finally, he shows how this new psychiatry is related to the urban cape and the colonial city with its modernity. He pointed out that western medical science arrived in India with colonialism. By mid-nineteenth century, lunatic asylums grew around the major metropolitan centers. By the early twentieth century, this new mental science had percolated to the vernacular periodicals of popular science.

Basu observed that the coming of psychiatry in India as a modern, rational and Eurocentric set of knowledge did not happen in a space full of magic, witchcraft and the like. Psychiatry here neither evolved from a naturally growing medical knowledge, nor did it follow a similar Foucauldian course that happened with Enlightenment in Europe. Its special character is marked by its coloniality in our case. Our modernity is from the very beginning deferred and different. The struggle of western rationalism in India was more insidious, complex and incomplete, more so in the case of psychiatry. Knowledge of western psychiatry in the Indian subcontinent was not only a colonial import but also had to negotiate a range of epistemological systems and cultural practices that were already operating here. He pointed out that unique relationships with western medical science bring a mind body divide in the understanding about mental illness. So, the coming of psychiatry in colonial India is a disjuncture in the sense that it brought in a new concept where the mind and the body are divided.

Throughout the world, the history of the relationship of psychiatry and colonialism cannot be traced in one singular pattern. There was a sharp difference between the Orientalist and Anglicist tradition regarding the introduction of 'Psychiatry' as a new science of mental illness.
In colonial India, the ways in which the British thought about their colonial subjects' minds, undoubtedly depict an integral part of the politics of the colonial rulers. The history of insanity in the age of colonial modernity was quite different from the then existing practice. Different studies reveal how the knowledge of colonial psychiatry was able to establish its hegemony in colonial India by making various negotiations with already set up systems of knowledge by both exclusion and appropriation. Such a discourse gave rise to a theoretical challenge in the history of insanity in the colonial India. In order to pave the colonial psychiatry in the Indian context, the colonial rulers forcefully attempted to introduce this new scientific culture where two incommensurable cultures met and a complex process of contest and consent was released which can be identified as 'cultural collision' (Beachum, Mc Cray, 2012). Throughout the colonial dynasty, the colonial force in India recognized the Indians as an unprogressive group and mission of new psychiatry was taken as a purposive attempt to save the Indians from their mental health problems. Indigenous healing, cultural elements of madness, discourse of madness and colonial modernity and psychiatry in India demonstrate that the number of studies portrayed regarding the concept of madness and its management is of particular cultural relevance. The dynamics of colonial power, rich and diverse history of India and conceptualization of madness - all were interwoven in the context of new asylum psychiatry and colonial discourse in the nineteenth century India.

\section{Conclusion}

Treatment of mentally ill was a common practice in this Indian subcontinent since time immemorial. Due to its cultural plurality, the treatment of insanity was manifested in different ways. Thus we get ample culture specific examples of treatment of mentally ill persons in different medical treatise. However, from the 
mid nineteenth century, new medical paradigms and psychiatric procedures came to influence the treatment of the mentally ill. Institutional treatment of the insane and provision of lunatic asylums in India came as a new colonial discourse and origin of asylums in different Presidencies can be placed at this juncture. While tracing the genesis of asylum history in British India, undoubtedly, the origin and activities of 'Madras Lunatic Asylum' occupied a distinct and unique position in its entirety. In its illustrious journey, the social situation became complex and these lunatic asylums became the epitome of profit making business. Along with other asylums, Madras Lunatic Asylums also faced several problems. The most important one was the medical identification of the proper insanes during admission in the asylums. In such a context, enactments of Indian Lunatic Acts were essential and enactment of Indian Lunacy Act of 1856 and Indian Lunacy Act of 1912 were of great importance. Enactment of these laws not only created a new vista in the asylum history of British India, but also drastically altered the concept of lunacy to a great extent. Here the role of the then Madras Government is undeniable. It was the Madras Govt. who first raised the issue of the admission of uncertified voluntary boarders in the asylum. In due course of time it was incorporated in the Indian Lunacy Act. While concluding the entire gamut of this discussion, it is worth mentioning that even in the colonial hegemony and being a colonial endeavour, Madras Lunatic Asylum always maintained its solemnity and austerity in different spheres of its activities like - good administration within asylum walls, cleanliness, indiscrimination of race and gender amongst the inmates and finally the uncontroversial financial matters. Initially the Madras Lunatic Asylum was established as a private mad house, mainly for the reception of European insanes irrespective of all social classes. But gradually it started the admission of lower class Europeans along with the Indians. In course of time this historical mad house became wretched and all the inmates were shifted to the new premises at Locock's Gardens which started working from 15th May 1871. All these unique features undoubtedly gave a remarkable position of this historical institution even in a colonial environment.

\section{ACKnowledgement}

Personal debts cannot be adequately acknowledged to all those who have come across during my research because they are so many. They all have extended their helping hands in unknown environs, both academic and geographic. I deeply acknowledge to the Indian National Science Academy. By way of giving me the Research Associateship it has helped me to facilitate this research work. I am also grateful to Dr.Sraboni Sen, Research Associate, INSA for her constructive academic guidance, Dr. Sukta Das, Research Associate, INSA; and Dr. Satarupa Dutta Majumdar, Post Doctoral Fellow, ICSSR for their editorial assistance. Last but not the least, I deeply acknowledge my indebtedness to academic and other sorts of generous help that I have obtained from Wellcome Trust Library, London; India Office Library, National Library of Scotland for their tremendous assistance whenever and wherever needed.

\section{BiBLIOGRAPHY}

Article of the Editorial Board. Experts and Criminal Lunatics, British Medical Journal, 20 (1864): 208-210.

Baiju, Gopal. The Concept of Madness and its Management: The Kerala Scenario, Unpublished PhD Dissertation, Department of Psychology, University of Calicut, Kerala, 2008.

Banerjee, Gauranga. First Psychiatric Clinic in a General Hospital in India, Mental Health Reviews, (2001), accessed from http://www.psyplexus.com/excl/fpcg. html $>$ on.

Basu, Amit Ranjan. A New Knowledge of Madness Nineteenth Century Asylum Psychiatry in Bengal, Indian Journal of History of Science, 39 (2004): 247-277. 
Basu, Amit Ranjan. Emergence of a Marginal Science in a Colonial City: Reading Psychiatry in Bengali Periodicals, Indian Economic and Social History Review, 41 (2004): 103-141.

Beachum, Floyd ; McCray, Carlos. What is Cultural Collision and Collusion? Paper presented at the Annual Meeting of the UCEAAnnual Convention, City Center Marriott, Denver, CO, Nov 15, 2012.

Blackstone, William. The study of the Law, Thomas, M, Cooley, Callagan \& Co., Chicago, 1871.

Brumlik, K C. Lunacy for Profit: The Economic Gains of 'Native Only' Lunatic asylums in the Bengal Presidency, 1850s - 1870s, Journal of South Asian Studies, 02 (2014): 1.

Crawford, D G. A History of Indian Medical Service, Vol.2, Thacker, Spink \& Co., London, 1914, p.395.

Ernst, Waltrud. Asylum Provision and the East India Company in the Nineteenth Century, Medical History, 42 (1998):476-502.

Ernst, Waltrud. Idioms of Madness and Colonial Boundaries: The Case of the European and Native Mentally ill in Early Nineteenth Century British India, Journal of Comparative Studies in Society and History, 39 (1997): 153-181.

Ernst, Waltrud. Mad Tales from the Raj: The European Insane in British India- 1800-1858, Anthem Press, New York, 1991, pp.95-96.

Ernst, Waltrud. Native Lunatic Asylum in Early Nineteenth Century British India, in G.Jan.Meulenbeld ; Dominik Wujastyk (ed), Studies on Indian Medical History, Motilal Banarasidass, Delhi, 2001, pp.155-188.

Ernst, Waltrud. The Madras Lunatic Asylum in the Early Nineteenth Century, Bulletin of the Indian Institute of History of Medicine, XXVII (1998):13-30.

Harrison, Mark. From Medical Astrology to Medical Astronomy: Sol-lunar and Planetary Theories of Disease in British Medicine, c. 1700-1850, The British Journal for the History of Science 33 (2000): 25-48.

Hill, O Berkeley. The Ranchi European Mental Hospital, Journal of Mental Science, LXX (1924): 68-76.

Hochmuth, C. Patterns of Medical Culture in colonial Bengal: 1835 - 1880, Bulletin of the History of Medicine, 80 (2006): 39-72.

Jain, Sanjeev. Psychiatry and Confinement in India, in Roy Porter, David Wright (ed), The Confinement of the Insane: International Perspective- 1800 - 1965,
Cambridge University Press, Cambridge, 2003, pp. $273-298$.

Keller, Richard. Madness and Colonization: Psychiatry in the British and French Empires - 1800 - 1962, Journal of Social History, 35 (2001):295.

Kolb, Lawrence C. Modern Clinical Psychiatry, W.B. Saunders Company, Philadelphia, 1968.

Macpherson, John. Report of the Lunatic Asylum in the Bengal Presidency, The Calcutta Review, 26 (1856): $592-602$.

Michael, A. Launer. The Peculiarities of the Confinement, History of Psychiatry, 5(1994):533 - 537.

Millard, Francine, Lunatic Asylum of British India: A National Library of Scotland Collection,UK, 2012.

Mills, James. The History of Modern Psychiatry in India : 1858 - 1947, Journal of the History of Psychiatry, 12 (2001): $431-458$.

Nizamie, S H; Goyal, N; Haq, M Z ; Akhtar, S. Central Institute of Psychiatry: A Tradition in Excellence, Indian Journal of Psychiatry, 50 (2008) :144 - 148.

Prioreschi, Plinio. A History of Medicine: Byzantine and Islamic Medicine, Horatius Press, Omaha, 2001.

Raison, C.L.; Klein,, H.M.; Steckler, M. The Moon and Madness Reconsidered, Journal of Affective Disorders, 53(1999):99-106.

Ramana, C. V. On the Early History and Development of Psychoanalysis in India, Journal of the American Psychoanal Association, 12(1964):110-134.

Riva, M. A., Tremolizzo, L.; Spicci, M.; Ferrarese, C.; De Vito, G.; Cesana, G. C.; Sironi, V. A. The Disease of the Moon: The Linguistic and Pathological Evolution of the English Term Lunatic. Journal of the History of the Neurosciences 20 (2011): 65-73,

Sastri, Pandit Kashinath. Caraka Samhitā of Agnivesa,Part I \& II, Cahukhamba Sanskrit Sansthan, Varanasi,1997.

Scull, A. T. A Convenient place to get rid of inconvenient people: The Victorian Lunatic asylum, in, A.D.King (ed), Buildings and Society, Routledge \& Kegan Paul, London, 1980, pp. 37-60.

Sharma, S.D. Mental Hospitals in India, Directorate General of Health Services, New Delhi, 1990.

Somasundaram et al, O. Treatment of the Mentally ill in the Chola Empire in 11-12th Centuries AD - A study of Epigraphs, Indian Journal of Psychiatry, 56(2014): 202-204. 
Somasundaram, O. Presidential Address : The Indian Lunacy Act 1912 - The Historic Background, Indian Journal of Psychiatry, 29 (1987): 3-13.

Somasundaram, O. Private Psychiatric Care in the Past: With Special Reference to Chennai, Indian Journal of Psychiatry, 50 (2008): 67-69.

Subba Reddy, D V. The Beginning of Modern Medicine in Madras: The Dawn of Modern Medicine in Madras, Thacker, Spink, Calcutta, 1947.

Subramanian, N. The Government Mental Hospital, Madras - A Short History, in O. Somasundaram, The Government Mental Hospital, Kilpauk, Memoirs of the Fifties, Madras, 2004.

Taylor, Col. M. Report of the Health Survey and Development Committee, Vol.3, Government of India Press, Simla, 1946.

Trivedi, J K. The Mental Health Legislation: An Ongoing Debate (editorial), Indian Journal of Psychiatry, 44 (2002) : 95-96.
Weiss, M G. The Treatment of Insane Patients in India in the Lunatic Asylums of the $19^{\text {th }}$ Century, Indian Journal of Psychiatry, 29 (1983): 312-316.

Wig, N.N. ; Awasthi, A.K. Origin and Growth of General Hospital Psychiatry, in S,P,Agarwal; D.S.Goel; R,L,Ichpujani; R,N,Salhan; S,Shrivattava (ed), Mental Health: An Indian Perspective - 1946-2003, Ministry of Health and Family Welfare, New Delhi, 2003,pp. 101-108.

Wise, T. A. Practical Remarks on Insanity as it Occurs among the inhabitants of Bengal, The Monthly Journal of Medical Science, 5(1852):174.

Woods, J H. The Yoga Sutras of Patanjali, Ginn \& Co., USA, 1914, p.434.

Wright, David. Getting out of the Asylum: Understanding the Confinement of the Insane in the Nineteenth Century, Course Collection, Module SHP- 252, 1997. 